АБРАДОВА Екатерина Сергеевна - магистрант факультета социологии и политологии Финансового университета при Правительстве РФ (125993, Россия, г. Москва, ГСП-3, Ленинградский $п р-\kappa m, 49)$

\title{
ВЗАИМООТНОШЕНИЯ ГОСУДАРСТВА И БИЗНЕСА РОССИИ В УСЛОВИЯХ САНКЦИОННОГО ДАВЛЕНИЯ ЗАПАДНЫХ CTPAH
}

\begin{abstract}
Аннотация. В статье автор рассматривает основные проблемы во взаимоотношениях власти и бизнес-сообщества в России в условиях санкционного давления Запада. Сегодня можно говорить о затянувшемся кризисе как о благоприятной возможности для развития на базе сосредоточения внутренних ресурсов и поиска новых точек роста. Поддержка предпринимательской инициативы и выстраивание партнерских отношений государства с бизнес-сообществом могут стать толчком к инновационному развитию страны и переходу России в лидеры экономического развития в мире.

Ключевые слова: бизнес, власть, санкции
\end{abstract}

B постсоветской России принципиальные характеристики, отражающие особенности сетевых связей государства и бизнеса, всегда относились к наиболее сложным для определения и исследования в силу фрагментированности, недостаточной укорененности, неформального характера деловых связей и неясного статуса основных акторов. В отличие от западных стран, в России в начале XXI в. только начался процесс формирования институциональных моделей взаимоотношений бизнеса и власти. После вхождения Республики Крым в состав России в 2014 г. отечественный бизнес принял на себя серьезный удар от западных санкций. В этих условиях сложно спорить с тем, что бизнес является одним из ключевых игроков и держателей ресурсов и интересов, способных влиять на процесс принятия политических решений. Поэтому новая институциональная модель взаимодействия власти и бизнеса может и должна стать основным внутренним фактором реализации антикризисных мер в условиях международных санкций.

Долгосрочный характер санкций и откровенное нежелание США и стран ЕС налаживать отношения и выстраивать равноправные партнерские отношения с Россией актуализируют вопрос о необходимости исследования трансформаций, происходящих в отношениях власти и бизнес-сообщества. Поэтапно наращивая санкционное давление, Запад создал для российского бизнеса две серьезные проблемы. Во-первых, секторальные санкции затруднили для бизнеса возможность более дешевого и «длинного» западного кредитования. Во-вторых, для российских компаний ограничен доступ к импортным технологиям. Секторальные санкции против российских политико-экономических структур ввели Канада, Япония, Швейцария, Австралия и другие страны. Российская Федерация ответила запретом на импорт продовольствия из стран EC, США, Канады, Японии и Австралии.

\section{Особенности взаимоотношений власти и бизнеса в условиях санкций}

В условиях санкционного давления и ограниченности внешних инвестиционных ресурсов новой тенденцией политических взаимоотношений власти и бизнеса России стала активизация взаимодействий между бизнес-структурами и институтами развития (Фонд содействия развитию малых форм предприятий 
в научно-технической сфере, государственная корпорация «Банк развития и внешнеэкономической деятельности (Внешэкономбанк)», ОАО «МСП-Банк», государственная корпорация «Российская корпорация нанотехнологий», OAO «Российская венчурная компания» и др.) в рамках партнерской модели [Борисов, Навроцкая 2015]. Появление новых институциональных структур российского бизнеса позволит не только укрепить эту тенденцию, но и способствовать налаживанию диалога между властью и бизнесом по конкретным направлениям деятельности и обеспечить представительство интересов отечественных предпринимателей в региональных и федеральных органах власти. Однако создание таких структур и обеспечение высокой эффективности их деятельности требует высокого уровня доверия среди представителей бизнессообщества.

Создание политических партий, объединяющих отечественных предпринимателей, эффективное функционирование бизнес-объединений как одного из каналов выстраивания гармоничных отношений с властью, а также продвижения интересов бизнеса и оказания влияния на принятие политических решений сегодня в России не является приоритетом для представителей бизнес-сообщества. Уровень доверия представителей бизнеса друг к другу в России крайне низок. Об этом свидетельствуют результаты авторского социологического исследования, проведенного в 2019 г. (см. рис. 1). 63,3\% малых и средних предпринимателей оценили уровень доверия представителей бизнес-сообщества друг к другу как «скорее низкий», 4,7\% - как «очень низкий», лишь $20 \%$ оценили его как «высокий».
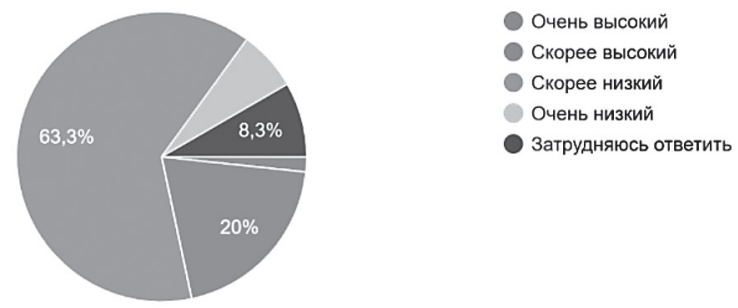

Рисунок 1. Как Вы оцениваете текущий уровень доверия представителей бизнес-сообщества друг к другу?

Эти показатели указывают на то, что на данный момент у предпринимателей не сложилось понимание, что объединение и создание возможности сообща влиять на политику могло бы стать грамотной стратегией реализации общих интересов. «Частным структурам важно понимать, что понятный и эффективный диалог с органами власти - это долгосрочный процесс, трудности в выстраивании которого связаны с различием в целях, подходах к управлению, а значит и в “картинах мира”» [Технологии и компетенции... 2018: 129].

Очевидно, что без поддержки делового мира невозможна ни одна избирательная кампания или крупный политический проект. Крупный бизнес, обладающий политическим ресурсом (капиталом), имеет возможность оказывать влияние на власть, тогда как интересы малого и среднего бизнеса по-прежнему не просто не учитываются, а зачастую игнорируются при принятии политических решений. Хотя именно малый и средний бизнес в развитых странах является основным каналом реализации новейших достижений НТП и вносит весомый вклад в экономику страны. Фактически современная российская власть теряет модернизационный и инновационный потенциал, который несут в себе пред- 
приятия малого и среднего бизнеса. Без государственной поддержки невозможны интенсификация промышленного производства, внедрение новых технологий, оптимизация использования ресурсов.

\section{Поддержка малого и среднего бизнеса в условиях санкций}

В октябре 2018 г. в России началась фактическая реализация национального проекта «Малое и среднее предпринимательство и поддержка индивидуальной предпринимательской инициативы». Основная цель данного нацпроекта - реализовать меры по поддержке предпринимателей на всех этапах развития бизнеса, начиная от появления идеи и заканчивая выходом компании на экспорт. Основные целевые показатели нацпроекта:

- численность занятых в сфере малого и среднего предпринимательства, включая индивидуальных предпринимателей, должна возрасти с 19,2 млн чел. в 2018 г. до 25 млн в 2024 г.;

- доля МСП в ВВП страны должна вырасти с 22,3\% в 2017 г. до 32,5\% в 2024 г;

- доля экспорта субъектов МСП в общем объеме несырьевого экспорта должна увеличиться с 8,6\% в 2017 г. до $10 \%$ в 2024 г. ${ }^{1}$

Реализация национального проекта предполагает развитие системы льготного налогообложения, упрощение получения кредитов и государственной поддержки (в т.ч. в системе госзакупок). Всего на исполнение нацпроекта планируется направить 481,5 млрд руб., из которых наибольшее финансирование планируется выделить в рамках федерального проекта по льготному кредитованию.

К сожалению, на сегодняшний день (спустя год с начала реализации нацпроекта) предпринимательское сообщество не только не видит эффективной реализации проекта, но и готовится к новым проблемам в ходе реализации своей деятельности, например к повышению налогов 2 . В этих условиях говорить о системной и продуманной политике в сфере поддержки предпринимательства как минимум преждевременно. В целом те условия, в которые поставлен современный российский бизнес, не позволяют предпринимателям продумывать и реализовывать долгосрочную стратегию развития собственного бизнеса. С этим утверждением согласны 67\% опрошенных предпринимателей (см. рис. 2).
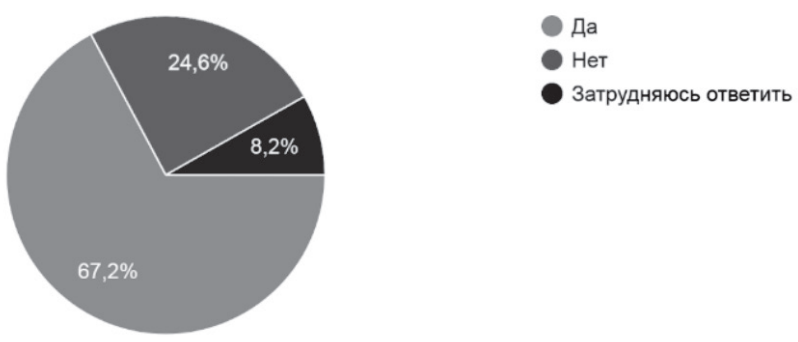

Рисунок 2. Как Вы считаете, сложно ли в современных российских условиях реализовывать долгосрочную стратегию развития бизнеса?

Совершенствование судебной системы, защита прав собственности, снижение налогов и исключение давления правоохранительных органов на сегодняшний день являются исключительно необходимыми условиями, при соблю-

\footnotetext{
1 Паспорт национального проекта «Малое и среднее предпринимательство и поддержка индивидуальной предпринимательской инициативы» - Правительство России. Официальный сайт. 2019 г. Доступ: http://government.ru/info/35563/ (проверено 03.11.2019).

2 Минэкономразвития объяснило рост налогов на малый бизнес. - РБК. 2019 г. Доступ: https://www. rbc.ru/economics/08/10/2019/5d9ba8389a7947655550478b (проверено 03.11.2019).
} 
дении которых бизнес может стать основой инновационного развития страны и перехода России в лидеры экономического развития в мире.

\section{Проблема «утечки мозгов» в предпринимательской сфере}

При сохранении сложившейся ситуации тенденция к «утечке мозгов» из предпринимательской сферы будет только усиливаться. Талантливые молодые предприниматели в условиях, предоставляемых бизнесу в других странах, видят сочетание больших возможностей и меньших рисков для создания и развития собственного дела. Таким образом, выходцы из России, переезжая в другую страну и ведя бизнес там, создают преимущества и повышают конкурентоспособность этой страны, а не России.

$50 \%$ опрошенных в ходе социологического исследования владельцев малого и среднего бизнеса готовы переехать и вести свое дело в другой стране, если представится такая возможность (см. рис. 3). Еще $20 \%$ респондентов затруднились дать ответ на поставленный вопрос. Лишь $30 \%$ предпринимателей отказались бы от такой возможности. Превышение оттока человеческого капитала над притоком ставит под серьезное сомнение перспективы входа России в состав мировых лидеров экономического развития.

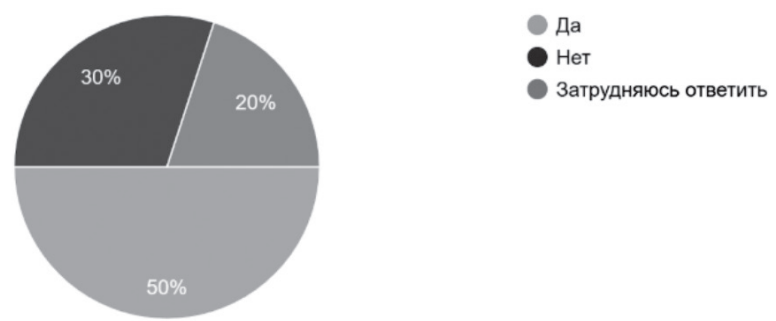

Рисунок 3. Если бы у вас появилась возможность переехать в другую страну и начать свое дело там, Вы бы согласились?

Те проблемы, с которыми сегодня сталкивается отечественный бизнес, являются прямым следствием неразработанности государственной политики в сфере поддержки предпринимательства, отсутствия полноценного диалога между государством и бизнесом. Введенные странами Запада санкции в целом усугубили существующие проблемы и привели к неблагоприятным последствиям для российской бизнес-среды. Сегодня власти и бизнесу необходимо делать шаги навстречу друг другу. В первую очередь это касается власти, которой необходимо минимизировать давление на предпринимательское сообщество в целях активизации предпринимательской деятельности и перехода к новому качеству экономического роста. Представители бизнес-сообщества, в свою очередь, должны активнее пользоваться мерами государственной поддержки и давать обратную связь по их эффективности.

Статья подготовлена в рамках реализации проекта РФФИ №19-011-31545 опн «Новые модели взаимодействия власти и промышленного сообщества в условиях возрастания рисков технологического развития под воздействием международных санкций».

\section{Список литературы}

Борисов С.Р., Навроцкая Ж.И. 2015. О роли объединенного бизнеса в продвижении интересов малого и среднего предпринимательства в современной 
России. - Бизнес и власть в России: формирование благоприятного инвестиционного и предпринимательского климата. М.: ИД ВШЭ. С. 66-77.

Технологии и компетенции $P R \& G R$ в условиях цифровой экономики: монография (под ред. С.Ю. Белоконева, 3.Р. Усмановой). 2018. М.: КноРус. 260 с.

ABRADOVA Ekaterina Sergeevna, $2^{\text {th }}$ year student of the Faculty of Sociology and Political Science, Financial University under the Government of the Russian Federation (49 Leningradsky Ave, Moscow, Russia, 125993)

\title{
RELATIONS BETWEEN GOVERNMENT AND BUSINESS IN RUSSIA UNDER THE SANCTIONS OF THE AUTHORIZED PRESSURE OF WESTERN COUNTRIES
}

\begin{abstract}
The article discusses the main problems in the relationship between the government and the business community in Russia under the sanctions pressure of the western countries. Today we can talk about the protracted crisis as a favorable opportunity for development based on the concentration of domestic resources and the search for new growth points. Support for entrepreneurial initiatives and building partnership between the state and the business community can be an impetus to the innovative development of the country and Russia's transition to the leaders of economic development in the world.
\end{abstract}

Keywords: business, government, sanctions

ИСАЕВ Дмитрий Петрович - кандидат исторических наук, доцент Института истории и международных отношений Южного федерального университета (344006, Россия, г. Ростов-на-Дону, ул. Б. Садовая, 105/42, disaew@mail.ru)

\section{ТРАНСФОРМАЦИЯ ОПЫТА ПРЕДПРИНИМАТЕЛЬСТВА В РОССИИ В КОНТЕКСТЕ ФОРМИРОВАНИЯ И ЭВОЛЮЦИИ ПРОФЕССИОНАЛЬНЫХ ДИНАСТИЙ}

\begin{abstract}
Аннотация. В статье рассматривается исторический опыт развития предпринимательства в России сквозь призму формирования и эволюции торгово-промышленных династий. Автор анализирует их характерные черты, ценностные установки и традиции, позволяющие видеть в купеческих семьях признаки профессиональных династий, проводит параллели сходства/различия между опытом династийности дореволюционного времени и нарождающимся в постсоветской России семейным бизнесом.

Ключевые слова: профессиональная династия, купечество, предпринимательство, преемственность, семейный контроль, трансмиссия статуса
\end{abstract}

$\mathrm{B}$ современных условиях формирования постнеклассической науки изучение социальных явлений характеризуется сложностью выработки исследовательских конструктов и применения различных концептов и понятий. Так, «профессиональные династии» (далее - ПД), родовое понятие социологической науки, сегодня как объект изучения все более формируется в междисциплинарном контексте. Династийность изучается в инженерной области, науке, трудовых и лицензируемых профессиях и др. [Инженерные династии... 2017; 